\title{
サイズが異なる構造物間における減衰特性の評価法および適用性 ESTIMATE METHOD OF DAMPING CHARACTERISTIC AND APPLICABILITY BETWEEN DIFFERENT SIZE STRUCTURES
}

\author{
脇田英治*，脇田健 裕**
}

\section{Eiji WAKITA and Takehiro WAKITA}

\begin{abstract}
An estimate method that used a parameter written $\boldsymbol{C}_{o}$ is proposed in this paper. It's possible to estimate the damping performance by using the parameter $\boldsymbol{C}_{o}$ between different size structures. Because the parameter $\boldsymbol{C}_{o}$ is dimensionless, the size of the structure is irrelevant to estimate. The applicability of this method was proven to be high by using the observed data. In addition, this paper proposes a method to presume the parameter of the proportional damping equation considering the scale effect. And, the characteristics of the proposed equation and the relationship with $\boldsymbol{C}_{o}$ were identified.
\end{abstract}

Keywords : Model, Vibration experiment, Proportional damping, Damping, Scale effect, Similarity law 模型, 振動実験, 比例減衰, 減衰, 寸法効果, 相似則

\section{1. はじめに}

建築構造物の耐震設計における大きな問題の 1 つは振動方程式に 含まれる減衰に関するパラメータの設定法や精度が不明確な点であ る。そのことが設計時の動的解析結果と現実の構造物の挙動の不一 致の原因の一つとなっている。この問題を解決する方法として，縮 小モデルの振動実験の利用が考えられる。すなわち，振動および減 衰のメカニズムが同一な縮小モデルの実験結果から減衰特性を評価 し，それを元構造物の減衰特性に換算して利用する方法である。

しかし，この方法は実構造物とその縮小モデル間に限らず，一般 的にサイズが異なる構造物間に存在する寸法効果が妨げとなり容易 ではない。すなわち，減衰メカニズムが同一という条件の下で，あ るサイズの構造物とその寸法を $1 /$ 入に縮小した構造物との間には表 1 に示すような相似則の成立することが知られており ${ }^{11,2), 3)}$ ，これ により元構造物の発生応力や変位は縮小構造物と単純な比例関係に はない。たとえば, 相似則によると, 長さの縮尺率が $1 / 10$ であれば, 模型の質量は $1 / 1000$, 剛性係数は $1 / 10$, 減衰係数は $1 / 100$, 固有振 動数は $1 / 10$ となる。このように項目毎に縮尺率はばらばらなので, あるサイズの構造物に対して相似則を完全に満足する縮小モデルを 用いる振動実験を実施することは困難である。
表 1 模型実験における相似則（文献 1)に加筆）

\begin{tabular}{|c|r|r|r|}
\hline 項目 & 単位 & 実物 & 模型 \\
\hline 質量 & $\mathrm{g}$ & 1 & $1 / \lambda^{3}$ \\
\hline 剛性係数 & $\mathrm{N} / \mathrm{cm}$ & 1 & $1 / \lambda$ \\
\hline 減衰係数 & $\mathrm{N} \mathrm{s} / \mathrm{cm}$ & 1 & $1 / \lambda^{2}$ \\
\hline 減衰定数 & - & 1 & 1 \\
\hline 時間 & $\mathrm{s}$ & 1 & $1 / \lambda$ \\
\hline 固有振動数 & $\mathrm{Hz}$ & 1 & $\lambda$ \\
\hline 変位 & $\mathrm{cm}$ & 1 & $1 / \lambda$ \\
\hline 速度 & $\mathrm{cm} / \mathrm{s}$ & 1 & 1 \\
\hline 加速度 & $\mathrm{cm} / \mathrm{s}^{2}$ & 1 & $\lambda$ \\
\hline
\end{tabular}

これに対する方策として, 遠心振動実験による方法 ${ }^{1), 2)}$ が比較的 有効ではあるが, 遠心振動実験においても元構造物に対して表 1 に 示す相似則を完全に満足する縮小モデルの振動実験の実施は困難 である。また，遠心実験は高価であり，かつ遠心載荷装置を装備す
* 国立群馬工業高等専門学校環境都市工学科 教授·工博 ** 中部大学工学部建築学科 助教.工修
Prof., Environmental Engineering Dept., Gunma National College of Technology, Dr. Eng. Assistant Prof., Dept. of Architecture, Chubu University, M. Eng. 
る機関も少ないので, 建築構造物の設計に対して実用的な方法とは 言い難い

サイズが異なる構造物間における減衰特性に関する既往の研究 ${ }^{4)}$ 〜 9) は少ないが, 次のようなものがある. 佐野ら ${ }^{4)}$ は加振機による実 験モード解析を実際の建物とその縮小モデルに適用し，相似則を考 慮して縮小モデルの振動実験結果を補正し, 実大構造物のモード解 析の結果と比較し，近似度の高いことを確認した。

この研究では縮小モデルの振動実験結果から比例減衰の仮定の もとに実大構造物の減衰比の推定が行われたが, 減衰係数までは推 定されていない。また, 使用した模型が 1 体のみなので, 仕様の変 化の影響までは明らかとなっていない。

飯場ら ${ }^{5)}$ は上部構造一杭基礎一地盤連成系の縮小モデルを用いた 振動台実験により共振振動数と減衰定数に関して連成系と基礎固定 系では両者に大きな差があること等を明らかにした。しかし，実験 の諸量の設定に関して相似則は部分的にしか満たされていないので, 縮小モデルの実験結果から元構造物の諸量を定量的に推定するまで には到っていない。

横川ら 6) は高架橋の縮小モデルの振動実験結果と数值解析の結果 を比較することにより基部からの逸散減衰を表すモデルの回転ダッ シュポットの減衰を示す減衰定数を逆算しているが, 元構造物とそ の縮小モデルとの関連性についての記述はない。

以上のようにサイズが異なる構造物間における減衰特性の関係や その評価法および適用性については十分に解明されていない。この 課題に対して, 本研究ではサイズの異なる構造物間における減衰特 性を統一的に評価する方法を提案し, その適用性について検討する。

最終的には縮小モデルを用いた振動実験結果から実構造物の減衰 特性を推定できる技術の確立が望ましいが，そのためには本研究の 成果の上に, さらにいくつかの課題(実物〜モデル間で減衰メカニズ ムの同一性をどのようにして確保するのか, 等) が存在する。本研究 の位置付けはその前段階であり, 対象をサイズの異なる構造物間に おける減衰特性の評価・適用性に限定して論じる。

\section{2. 無次元化減衰係数の誘導とそれを用いた減衰特性の評価法 (1) 無次元化減衰係数 $C_{0}$ の誘導}

地震動を受ける建築構造物を模擬した模型振動実験により得ら れる相対加速度 $\ddot{x}$, 相対速度 $\dot{x}$, 相対変位 $\boldsymbol{x}$ (すべて各階の值を 要素に持つベクトル), および地動加速度パラメータ $\boldsymbol{u}_{\boldsymbol{s}}$ は次の振動 方程式に従う。

$$
\boldsymbol{M} \ddot{\boldsymbol{x}}+\boldsymbol{C} \dot{\boldsymbol{x}}+\boldsymbol{K} \boldsymbol{x}=-\boldsymbol{M}[1] \boldsymbol{u}_{\boldsymbol{s}}
$$

ここに $M, C, K$ (すべてマトリックス)はそれぞれ質量, 減衰係 数, 剛性係数, [1]は要素が全て1の行列である。

この式に含まれる $\ddot{\boldsymbol{x}}, \dot{\boldsymbol{x}}, \boldsymbol{x}, \boldsymbol{u}_{\boldsymbol{s}}$ に対して式 (2)の関係にある状態量 $\ddot{X}, \dot{X}, X, U_{t}$ を定義する。

$$
\begin{gathered}
D=\left(K^{-1} M\right)^{-0.5}, \quad \quad \ddot{X}=D^{-1} \ddot{x}, \quad \dot{X}=D^{-1} \dot{x}, \\
X=D^{-1} x, \quad U_{t}=-D^{-2}[1] u_{s}
\end{gathered}
$$

式(2)に含まれる $\boldsymbol{M}, \boldsymbol{K}$ は模型振動実験の仕様から計算により推 定可能であり, 時刻歷データ $\ddot{\boldsymbol{x}}, \dot{\boldsymbol{x}}, \boldsymbol{x}, \boldsymbol{u}_{\boldsymbol{s}}$ も加速度計, 変位計で計測で きるので，それらの值を用いて式(2)の值は模型振動実験結果から 求めることができる。

次に, 式(2)の関係を式(1)に代入し, 式を整理すると次式が得ら
れる。

$$
D^{-1} \ddot{X}+C_{o} \dot{X}+D X=U_{t}
$$

ここに， $C_{0}$ は次式で与えられる無次元量である。

$$
\boldsymbol{C}_{\mathrm{o}}=\boldsymbol{K}^{-1} \boldsymbol{C}\left(\boldsymbol{K}^{-1} \boldsymbol{M}\right)^{-0.5}
$$

式(3)の未知パラメータは $\boldsymbol{C}_{0}$ のみ $(\boldsymbol{D}$ は構造仕様から推定できる ので)であるが， $\boldsymbol{C}_{0}$ の值は模型振動実験結果の結果を用いたシステ ム同定により求めることができる。この $\boldsymbol{C}_{0}$ 值は無次元量(単位の無 い係数)であるため, 寸法に無関係で, 減衰入カニズムが同一であ れば，模型に対してもそれを拡大したサイズの構造物，さらに実大 構造物に対しても一定值である。

\section{(2) $\boldsymbol{C}_{0}$ の特性評価に用いる振動実験データ}

次節で実例を用いて減衰に関する $\boldsymbol{C}_{0}$ の特性を検討する。本節では その実例としての模型振動実験の方法と結果について記述する。図 1 は振動台に設置された 2 層フレーム構造の模型とそれを 2 質点系 (2 層せん断型モデル)でモデル化した場合のモデル図を示している。 模型の図にダンパーが取り付けられているが，ダンパーは着脱可 能であり, 本 Case ではダンパー無しの状態で実験を実施している (2. (3) で後述するCase4 では同じ装置でダンパー有りの状態で実験 を実施）。データ採取は各所（図 1 参照）に配置された加速度計と 変位計で行い, 動ひずみ測定器を介して, 0.01 秒間隔の時系列デー タとしてハードディスクに収録した。

図 2 は振動台の面上に設置された加速度計で計測された時系列デ 一夕(絶対加速度)であり, これは図 1 に示寸 2 質点系モデルの下端 に入力される加速度に相当するものである。この波形はエルセント 口NS 波の波形を元にして振幅と振動数を模型実験用に調整したも のである。それに対して, 図 3 は模型の 2 階天端位置に設置された 加速度計で計測された時系列データ(絶対加速度)である。
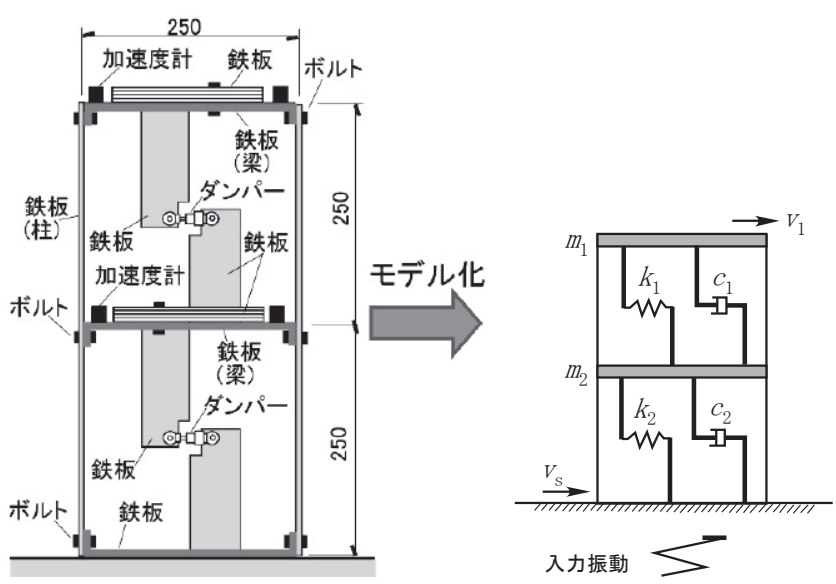

図 1 振動模型と解析モデル

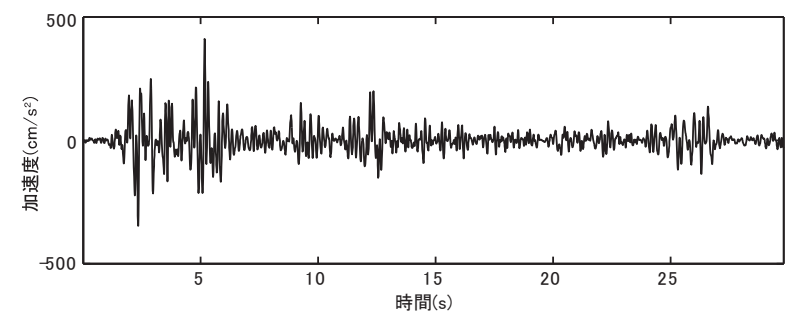

図 2 入力加速度 


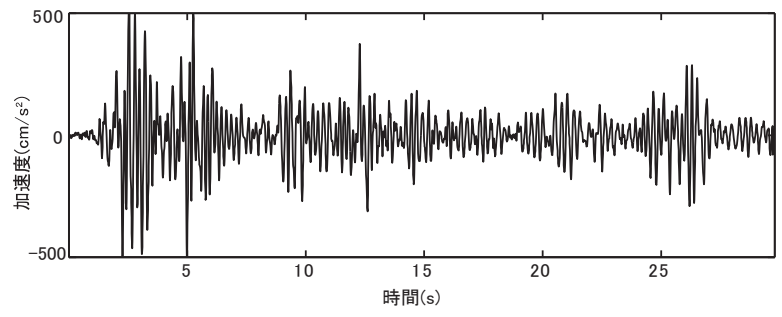

図 3 応答加速度 $(2$ 階天端位置 $)$

表 2 動的パラメータ值

\begin{tabular}{|c|c|c|c|}
\hline & $\begin{array}{c}\text { 質量 } \\
m_{\mathrm{i}}(\mathrm{g})\end{array}$ & $\begin{array}{c}\text { 剛性係数 } \\
k_{\mathrm{i}}(\mathrm{N} / \mathrm{cm})\end{array}$ & $\begin{array}{c}\text { 減衰係数行列 } \\
\boldsymbol{C}(\mathrm{N} \mathrm{s} / \mathrm{cm})\end{array}$ \\
\cline { 1 - 2 } 2 階 & 3070 & 39.8 & {$\left[\begin{array}{rr}0.0 & 0.0 \\
0.0 & 9.39\end{array}\right] \times 10^{-2}$} \\
\hline 1 階 & 1310 & 30.8 & \\
\hline
\end{tabular}

表 2 に入力加速度 (図 2), 2 階の応答加速度 (図 3)データを用いた システム同定により得られたパラメータ值が示されている。表 2 に おいて質量は構造仕様から設定したものであり，剛性係数と減衰係 数は同定により得られたものである。

システム同定には文献 10)の方法を用いた。この方法の特徴は解析 が 2 段階に分かれていることである。第 1 段階でパラメータの概略 值の推定を行い，それを初期值として第 2 段階で最適化手法を用い て目的関数を最小にすることによりパラメータ解を得ることができ る。

図 4 および図 5 はこの方法によるシステム同定の結果を観測デー タと比較したものである。それらのうち, 図 4 は入力加速度に対す る 2 階応答加速度の周波数伝達関数であり, 図中の点線は観測デー 夕，実線は同定結果を示している。両者はよく一致している。

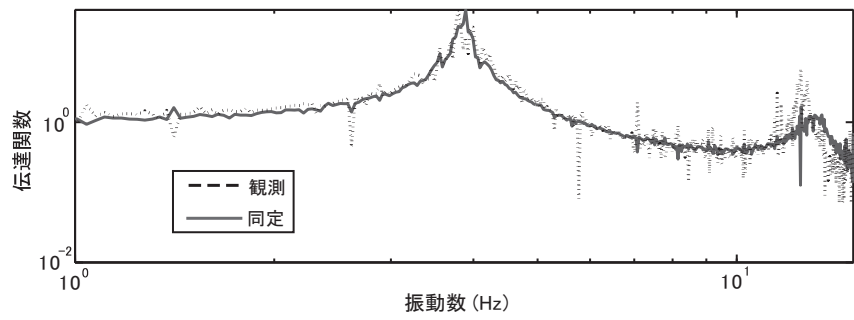

図 4 同定結果 (2 階の応答加速度) と観測データの比較

同様に，図 5 は入力加速度に対する 1 階応答加速度の周波数伝達 関数を表しているが，こちらも点線の観測データは実線の同定結果 とよく一致している。

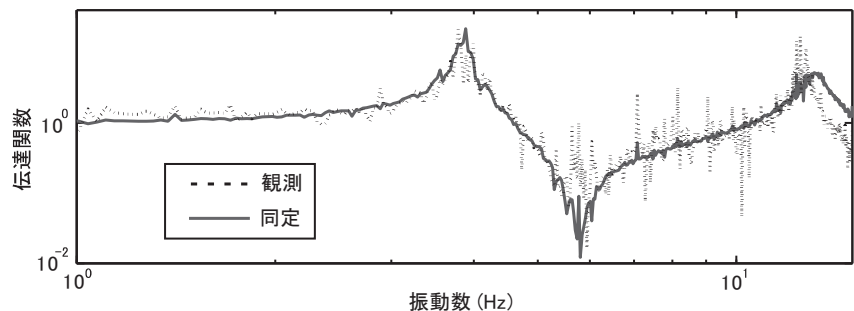

図 5 同定結果 ( 1 階の応答加速度) と観測データの比較
以上のことから本実験データに関するパラメータの同定精度は良 好であると考えられる。

\section{(3) 減衰に関する $C_{0}$ の特性}

式(1)に含まれる通常の減衰係数 $\boldsymbol{C}$ の場合には, その值がたとえ 一定であったとしても, 構造物のサイズや他のパラメータが変化す ればそれに応じて構造物の減衰特性も変化する。それに対して，式 (4) の無次元化減衰係数 $\boldsymbol{C}_{0}$ の場合には，たとえ，構造物のサイズや 他の動的パラメータが変化したとしても， $\boldsymbol{C}_{\mathbf{0}}$ が無次元量であること が寄与して， $C_{\mathbf{0}}$ で表される減衰特性は変化せず，一定值を保つ。こ こではそのような $\boldsymbol{C}_{\mathrm{o}}$ の減衰特性について検討する。

まず，式(3)に含まれる係数・状態量を要素に持つ次のような行 列を定義する。

$$
A_{\mathrm{c}}=\left[\begin{array}{cc}
{[0]} & \boldsymbol{I} \\
-D^{2} & -D C_{0}
\end{array}\right], \quad \mathbf{B}_{\mathrm{c}}=\left[\begin{array}{c}
{[0]} \\
-I
\end{array}\right] D^{-1}, X_{\mathrm{n}}=\left\{\begin{array}{l}
\boldsymbol{X} \\
\dot{X}
\end{array}\right\}
$$

ここに，Iは単位行列，[0]は要素が 0 の行列である。式(5)を用 いて，式(3)を書き直すと，次式となる。

$$
\dot{\boldsymbol{X}}_{\mathrm{n}}=\boldsymbol{A}_{\mathrm{c}} \boldsymbol{X}_{\mathrm{n}}+\boldsymbol{B}_{\mathrm{c}}[1] u_{\mathrm{s}}
$$

式(6)をラプラス変換して, 複素数 $s$ を $s=i \omega$ とおくと, 次式が得 られる。ここに， $i$ は虚数， $\omega$ は円振動数である。

$$
u_{\mathrm{s}}=\left(\boldsymbol{B}_{\boldsymbol{c}}[1]\right)^{-\mathbf{1}}\left(i \omega \boldsymbol{I}-\boldsymbol{A}_{\boldsymbol{c}}\right) \boldsymbol{X}_{\mathrm{n}}
$$

式 (7) に含まれる $\boldsymbol{X}_{\mathrm{n}}$ は構造物の各階の変位・速度に関する状態量 を要素に持つ行列であるが，その中から例として図 1 の解析モデル に示す 2 質点系の 2 階部分の応答速度 $v_{1}$ を取り出すと次式となる。

$$
v_{1}=\boldsymbol{E}_{1}\left[\begin{array}{cc}
\boldsymbol{D} & {[0]} \\
{[0]} & \boldsymbol{D}
\end{array}\right] \boldsymbol{X}_{\mathrm{n}}
$$

ここに, $\boldsymbol{E}_{1}$ は行列の中から任意の要素を取り出すために掛ける 係数行列であり,図 1 に示すような 2 質点系の場合は, $\boldsymbol{E}_{1}=\left[\begin{array}{llll}0 & 0 & 1 & 0\end{array}\right]$ である。3 質点系以上の場合には $\boldsymbol{E}_{1}$ の要素が変わるだけで式(8) 自体は同一である。

以上の関係を用いて, 速度 $v_{1}$ の地動速度 $v_{s}$ に対する伝達関数 $\boldsymbol{G}_{\mathrm{s}}$ は次式で表すことができる。

$$
\boldsymbol{G}_{\mathbf{s}}=\frac{v_{1}}{v_{s}}=\frac{v_{1}}{\boldsymbol{u}_{s} / \boldsymbol{s}}=\boldsymbol{E}_{\mathbf{1}}\left[\begin{array}{cc}
\boldsymbol{D} & {[0]} \\
{[0]} & \boldsymbol{D}
\end{array}\right]\left(i \omega I-\boldsymbol{A}_{\boldsymbol{c}}\right)^{-\mathbf{1}} \boldsymbol{B}_{\boldsymbol{c}}[1] i \omega
$$

次に，この伝達関数 $\boldsymbol{G}_{\mathbf{s}}$ を用いた構造物の減衰特性の評価法につい て前述の 2. (2) の実験データ (表 2 のパラメータ)を用いて検討する。

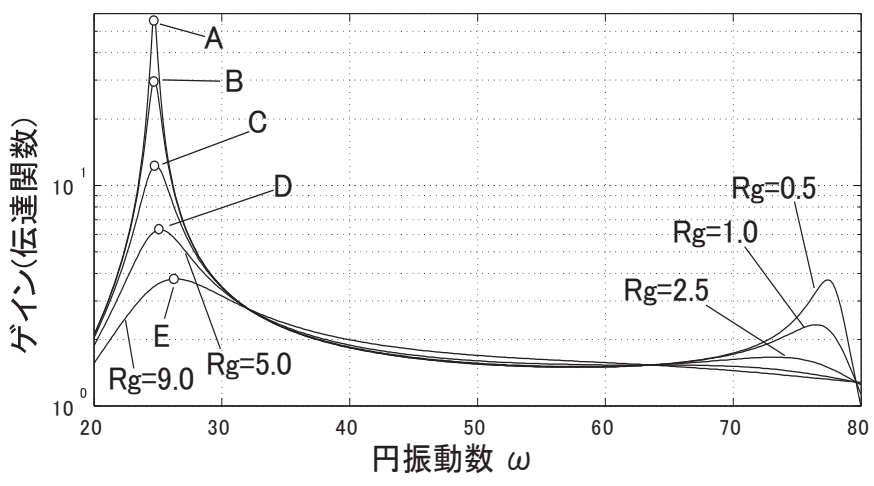

図 $6 \boldsymbol{C}_{\mathbf{0}}$ 值の変化に対する伝達関数 $(2 \mathrm{~F}$ 速度)の特性 
表 2 のパラメータを式 (9) に代入する。得られる伝達関数 $\boldsymbol{G}_{\boldsymbol{s}}$ は複 素数であるため, $(a+b i)$ の形式であるが, その $\left(\sqrt{a^{2}+b^{2}}\right)$ を $\mathrm{y}$ 軸に, 円振動数 $\omega$ を $\mathrm{x}$ 軸にとって図に表したものが図 6 である。

図 6 には $R_{\mathrm{g}}=0.5 \sim 9.0$ と表示された 5 本の曲線が示されている。 $R_{\mathrm{g}}=1.0$ とは表 2 に対応寸るケースである。それに対して, $R_{\mathrm{g}}=0.5$, 2.5, - - 一表示されている曲線は $\boldsymbol{M}$ と $\boldsymbol{K}$ はそのままで， $\boldsymbol{C}_{0}$ 值のみ を表 2 のケースの 0.5 倍, 2.5 倍, - - - した時の曲線である。この

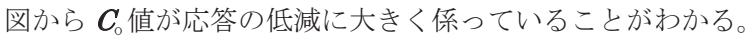

$M$ と $K$ の值を変化させると, 図 6 の曲線の位置やスケールは変 化するが, $\boldsymbol{C}_{\mathbf{0}}$ 值の変化に対する応答の低減特性は変わらない。図 7 はこの様子を表している。すなわち， $\boldsymbol{M}$ と $\boldsymbol{K}$ の值を表 2 の $0.5 \sim 2$ 倍の範囲で変化させた各ケースについて応答の低減特性を調べたの が図 7 である。

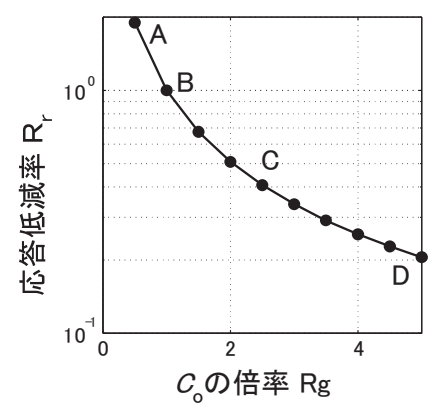

図 7 応答低減への $C_{\mathbf{0}}$ の影響

図 6 に示す点 $\mathrm{A} \sim \mathrm{E}$ のようなスペクトル曲線のピーク值に着目し， その值を $R_{\mathrm{g}}=1.0$ の曲線のピーク值(図 6 の $\mathrm{B}$ 点) で割った值(応答低 減率) $R_{\mathrm{r}}$ を $\mathrm{y}$ 軸にとり, $C_{\mathbf{0}}$ の倍率 $R_{\mathrm{g}}$ を x 軸にとって, 両者の関係を プロットしている。

図 7 には $M$ と $\boldsymbol{K}$ を変化させた全部で 16 ケースの曲線がプロッ 卜されているが，それらは全て重なり，1本の曲線にしか見えてい ない。つまり, $\boldsymbol{M}$ と $\boldsymbol{K}$ 等, 他のパラメータ值には無関係に, 無次 元量である $C_{0}$ の值によって応答の低減特性が一律に決まっている 様子がわかる。この関係は構造物のスケールにも無関係である。

\section{(4) $C_{0}$ を用いた減衰特性の評価法と適用性}

2. (3) で示した図 7 は $\boldsymbol{C}_{0}$ の特性を簡明に表しているが，特性を定 量的に取り扱う上で次の理由により普遍性に欠ける。すなわち, 図 7 のX軸の $\boldsymbol{C}_{\mathrm{o}}$ の倍率 $R_{\mathrm{g}}$ はたまたま例として取り上げたある模型振 動実験データのケースにおける $\boldsymbol{C}_{0}$ の值を基準として，それに対す る各解析ケースの倍率を示している。ところが， $C_{0}$ は行列であり， その要素の構成比率は条件によって変化するので, 一実験值に対す る倍率のみに着目した図 7 の X 軸の $C_{0}$ の倍率 $R_{\mathrm{g}}$ は様々な構造条件 に対する一般的な減衰特性を定量的には表していない。また，図 7 の $\mathrm{Y}$ 軸も図 6 の $\mathrm{B}$ 点を基準としてそれに対する比率として応答低減 率 $R_{\mathrm{r}}$ を定義しているが, 図 6 の $\mathrm{B}$ 点はたまたま選ばれた点であり， 減衰特性を定量的に評価する上では不適切である。

この課題に対して, X 軸については $C_{0}$ の倍率 $R_{\mathrm{g}}$ の代わりに $C_{\mathrm{o}}$ の 固有值を用いることにより対処する。 $C_{0}$ は正方行列であるので，そ の固有值を求めることができる。固有值は複数存在するが, その最 大值を採用し, 以後, それを $C_{0}$ の固有值と呼ぶ。他方, $\mathrm{Y}$ 軸につ いてはB 点の代わりに $[\mathrm{A} \rightarrow \mathrm{B} \rightarrow \cdots \cdot \mathrm{E} \rightarrow]$ と変化させた時に
最終的に到る最下点を用いることにより対処する。そこで，このよ うな一般化された指標を用いて, 実際に種々の条件下で行われた実 験データ（表 3 参照）に対する解析結果を整理し， $\boldsymbol{C}_{\mathbf{0}}$ の減衰特性を 評価する。

表 3 模型振動実験の仕様・パラメータ同定值

\begin{tabular}{|c|c|c|c|c|c|}
\hline & 階 & $\begin{array}{l}\text { 質量 } \\
m_{\mathrm{i}}(\mathrm{g})\end{array}$ & $\begin{array}{l}\text { 剛性係数 } \\
k_{\mathrm{i}}(\mathrm{N} / \mathrm{cm})\end{array}$ & $\begin{array}{c}\text { 減衰係数行列 } \\
\boldsymbol{C}(\mathrm{N} \text { s/cm) }\end{array}$ & $\begin{array}{c}\text { サイズ比 } \\
\lambda\end{array}$ \\
\hline \multirow[t]{2}{*}{ Case 1} & 2 & 3070 & 39.8 & \multirow{2}{*}[\begin{array}{cc}{0.0}&{0.0}\\
{0.0}&{9.39}\end{array}]{$\times 10^{-2}$} & \multirow[t]{2}{*}{2.63} \\
\hline & 1 & 1310 & 30.8 & & \\
\hline \multirow[t]{2}{*}{ Case 2} & 2 & 87.7 & 0.532 & \multirow{2}{*}{$\left.\begin{array}{c}-1.14 \\
2.21\end{array}\right] \times 10^{-3}$} & \multirow[t]{2}{*}{1.00} \\
\hline & 1 & 59.5 & 0.460 & & \\
\hline \multirow[t]{2}{*}{ Case 3} & 2 & 76.9 & 0.768 & \multirow{2}{*}{$\begin{array}{c}1.61 \\
-1.40\end{array}$} & \multirow[t]{2}{*}{1.00} \\
\hline & 1 & 55.7 & 0.767 & & \\
\hline \multirow[t]{2}{*}{ Case 4} & 2 & 2880 & 52.4 & \multirow{2}{*}[\begin{array}{cc}{0.279}&{-0.050}\\
{-0.050}&{0.223}\end{array}]{} & \multirow[t]{2}{*}{ 2. 63} \\
\hline & 1 & 1540 & 52.4 & & \\
\hline
\end{tabular}

表 3 には解析に用いる 4 Case の実験データが示されている。これ らの実験はいずれも図 1 に示す 2 質点系モデル (2 層せん断型) に相 当する模型振動実験であるが，実験条件は異なる。すなわち，模型 のサイズや質量・剛性の大きさ・分布がそれぞれ異なる。

表中の Case1 は前述の 2. (2) で示した実験データと同一のもので ある。その模型の構造や解析モデル, 計測方法および加振の方法を 前述の 2. (2) で記述したが, Case2〜Case4 についても模型のサイズ 以外は Case1 とほぼ同じである。模型のサイズはサイズ比えとして 表 3 に表示されている。これはCase2 の模型の高さを 1.0 とした場 合の各 Case の模型高さを比率で表示したものである。

前述の 2. (2)に示した模型にダンパーが表示されていたが, Case1 〜Case3 についてはダンパー無し, Case4 についてダンパー有りの 状態で振動実験を実施した。また, Case2, Case4 において模型の下 端から入力された加速度は Case 1 と同様，エルセントロ NS 波の波 形を元にして振幅と振動数を模型実験用に調整したものである。 Case3 の入力波はランダム波である。

表 3 には実験データ（振動台面上の入力加速度と 2 階天端の応答加 速度データ)を用いたシステム同定により得られたパラメータ值が 示されている。表 3 において質量は仕様から設定したものであり, 剛性係数と減衰係数は同定により得られたものである。システム同 定には文献 10)の方法(詳細は前述の 2. (2) 参照)を用いた。

以下に示寸図 8〜図 10 はこの方法によるシステム同定の結果を観 測データと比較したものである。これらの図において実線および点 線は入力加速度に対する 2 階応答加速度の周波数伝達関数を表して おり，点線は観測データ，実線は同定結果に対応している。

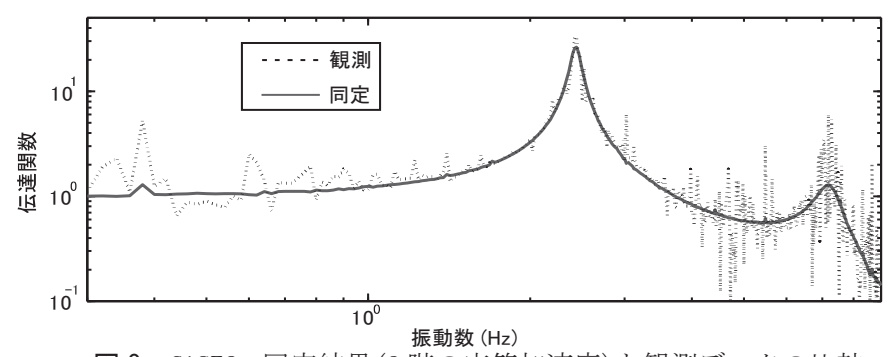

図 8 CASE2 : 同定結果 (2 階の応答加速度) と観測データの比較 


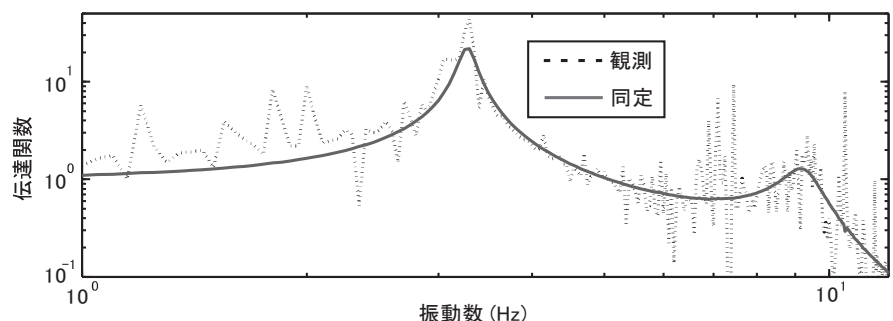

図 9 CASE3 : 同定結果 (2 階の応答加速度) と観測データの比較

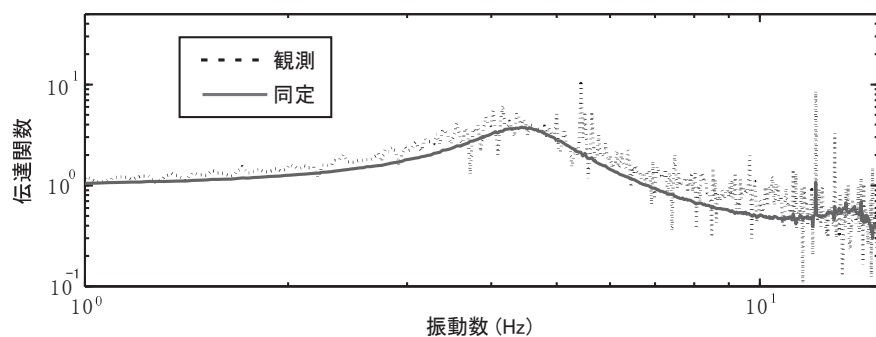

図 10 CASE4：同定結果 (2 階の応答加速度) と観測データの比較

比較の結果, いずれの Case においても両者はよく一致しており, これらのことからパラメータの同定精度はいずれも良好であると考 えられる。

これら実験結果から次に示寸解析手順に従って $\boldsymbol{C}_{\mathbf{0}}$ の減衰特性を検 討する。

\section{解析手順}

1) 表 3 に示す 4Case の実験データを用いて, 動的パラメータ $\boldsymbol{M}, \boldsymbol{C}, \boldsymbol{K}$ を求める。

2） $\boldsymbol{M}, \boldsymbol{C}, \boldsymbol{K}$ を用いて，前述の式(4)により $\boldsymbol{C}_{\mathbf{0}}$ の值を求める。

3) $\boldsymbol{C}_{\mathbf{0}}$ の值を 0.5 25 倍の範囲で変化させ, 前述の式(9) を用いて伝 達関数を計算する。

4）伝達関数の計算值から次式により応答低減比 $R_{\mathrm{s}}$ を計算する。

$$
R_{\mathrm{s}}=\frac{y_{I}}{y_{O}}
$$

ここに $y_{0}$ は基準ピーク值である。この值は次のように求める。伝 達関数のスペクトル図 (図 6 参照)において $\boldsymbol{C}_{\mathbf{0}}$ を大きくしていく と $[\mathrm{A} \rightarrow \mathrm{B} \rightarrow \cdots \rightarrow \mathrm{E} \rightarrow]$ と変化して行くが，あるところでそ れ以上はピーク值が低下しなくなる。その時のピーク值を基準ピ 一ク值と呼ぶ。また, 式(10)において $y_{1}$ とは各 $\boldsymbol{C}_{\mathbf{0}}$ に対する伝達 関数スペクトルのピーク值（たとえば図 6 の A, B,・・,E）であ る。

5） $\boldsymbol{C}_{\mathbf{0}}$ の固有值 $\mu_{\mathrm{c}}$ をX 軸に, 応答低減比 $R_{\mathrm{s}} を \mathrm{Y}$ 軸にとり, 両者の 関係をプロットする。

図 11 は以上の解析手順より得られた $\boldsymbol{C}_{\mathbf{0}}$ の固有值と応答低減比の 関係を示している。図 11 の実線はCase4 において $\boldsymbol{C}_{\mathbf{0}}$ 值を変化させ て得られたものである。それに対して ${ }^{1}$ 記号は Case1 の $\boldsymbol{C}_{\mathbf{0}}$ 值が 1 倍の位置, $\triangleleft^{2}$ 記号はCase1 の $\boldsymbol{C}_{\mathbf{0}}$ 值が 2 倍の位置を表している。 同様に, $\star^{1}, \star^{2}$ は Case2, ・ ${ }^{1},{ }^{2}$ は Case $3, \mathrm{O}^{1}, \mathrm{O}^{2}$ は Case4 に対応しており，それぞれ $C_{0} 1$ 倍位置，2 倍位置を表している。

図によるとCase4 の実線と各 Case の $\boldsymbol{C}_{\mathbf{0}} 1$ 倍位置，2 倍位置がす べて一致している。また，煩雑となるため図には表示されていない が，各 Case 毎に $\boldsymbol{C}_{\mathbf{0}}$ 值を変化させて得られる曲線もほぼすべて重な る。つまり，実験条件(模型のサイズ，質量，剛性等)の差異に関わ らず, $\boldsymbol{C}_{\mathbf{0}}$ の固有值によって応答の低減特性が一律に決定されること

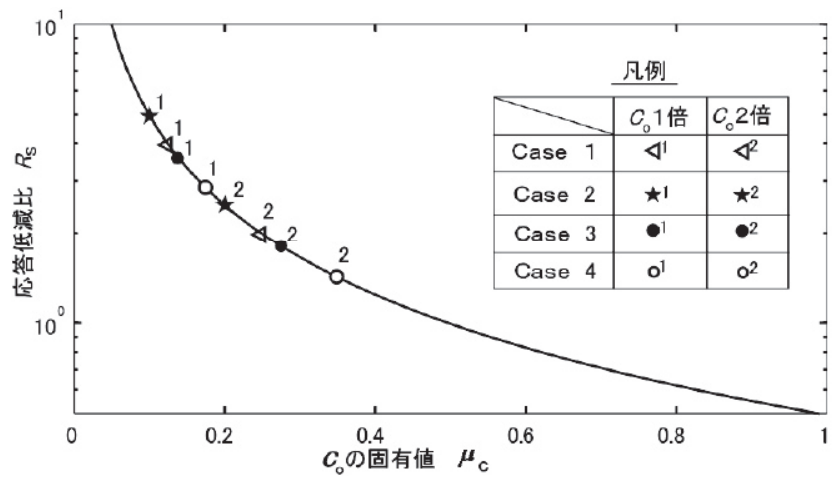

図 $11 C_{0}$ の固有值と応答低減比の関係

がわかる。このことは, 比較しようとする構造物間でサイズに相違 があるとしても，それらについて $\boldsymbol{C}_{\mathbf{0}}$ の固有值を求め，図 11 にプロ ット寸れば応答の低減特性（減衰性能のレベル）を把握できること を意味している。

\section{(5) $C_{0}$ と減衰定数の関係}

減衰定数は $C_{0}$ と同様，減衰の度合いを表す無次元量である。そ の意味において両者は類似している。本節では両者の違いや関係を 調べることにより，減衰定数に無い $\boldsymbol{C}_{0}$ の特徴を明らかにする。

1 自由度系の振動方程式

$$
m \ddot{x}+c \dot{x}+k x=f
$$

において $c=2 h \quad \omega_{0} m, k=\omega_{o}^{2} m$ と置くことが可能な場合, こ れらの関係式を前述の式(4)に代入すると, 次式が導かれる。ここに, $m$ は質量, $h$ は減衰定数, $\omega_{0}$ は固有円振動数である。

$$
C_{0}=2 h
$$

つまり, この場合には無次元化減衰係数 $C_{0}$ と減衰定数 $h$ はほぼ 同じ意味を持つことをこの式は示している。

しかし，現実の構造物においては，1自由度系といえども構造減 衰等の影響により減衰係数 $c$ が $2 h \omega o m$ と等しくなることはま れである。そこで， 1 自由度系の一般的なケースとして減衰係数 $c$ を $\left(2 h \omega_{0} m+\alpha\right)$ と表せる場合を対象に $C_{0}$ と減衰定数 $h$ の関 係について検討する。ここに， $\alpha$ は構造減衰等の影響による減衰係 数の増加分である。

ケーススタディとして $, h=0.05, k=\omega_{0}^{2} \mathrm{~m}, \alpha=2.0 \times 10$ $\mathrm{Ns} / \mathrm{cm}$ とし， $\omega_{0}$ と $m$ を $\omega_{0}=10.2 \sim 14.0 ， m=(1.1 \sim 3.0) \times 10^{4} \mathrm{~g}$ の範囲で変化させ，式(4)を用いて $z=C_{0} / h$ の值を求める。その結 果を $\mathrm{X}$ 軸に $\omega_{0}$, $\mathrm{Y}$ 軸に $m, \mathrm{Z}$ 軸に $z$ をとってプロットしたもの が図 12 である。

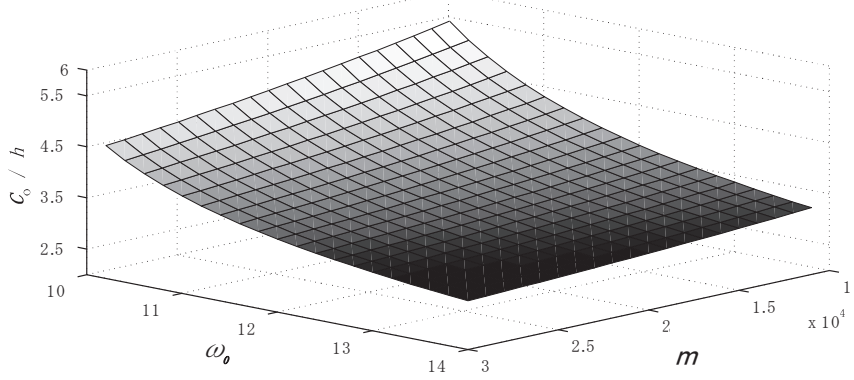

図 $12 C_{0}$ と減衰定数の関係 
図によると $\omega_{0}$ と $m$, どちらの変化に対しても， $\mathrm{z}=C_{0} / \mathrm{h}$ は変化し ている。つまり，たとえ 1 自由度系であっても $c=2 h \omega_{0} m+\alpha$ とい う一般的な場合には $C_{0}$ と減衰定数 $h$ は別ものであることがわかる。 さらに, 多次元系の場合には $\boldsymbol{C}_{0}$ は行列であるが, 減衰定数 $h$ は変数 であり, 両者はその点でも異なる。つまり, $\boldsymbol{C}_{\mathbf{r}}$ は減衰定数と異なり, 構造減衰や地下逸散減衰等の影響も含めた減衰特性を絶対評価でき る指標であり, かつ多次元系の減衰特性も評価できる特徴を有する と考えられる。

なお, 以上の検討では式(11)において $c=2 h \omega_{0} m$ と置いたが, その代わりに $\mathrm{c}=2 \mathrm{~h} / \omega_{0} k$ と置くことも可能である。しかし, $k$ と $m$ の関係式 $k=\omega_{o}^{2} m$ を後者の式に代入すれば, 前者の式が得られる。 つまり, 代わりに $c=2 h / \omega_{0} k$ と置いても前述の検討結果は同じで ある。

\section{3. 比例減衰式のスケール特性と $C_{0}$ の関係}

\section{(1) 比例減衰に基づく減衰係数の一般的な推定法}

一般に建築構造物の構造設計において減衰係数を設定しょうと する場合，比例減衰式を用いることが多い。「レイリー型」，および 「剛性比例型」の推定式はその場合の代表的な推定式であるが, 式 の構成は次のとおりである。

レイリー型の減衰係数の推定式

$$
\begin{gathered}
{\left[\begin{array}{l}
a_{0} \\
a_{1}
\end{array}\right]=\frac{1}{\omega_{2}^{2}-\omega_{1}{ }^{2}}\left[\begin{array}{cc}
\omega_{2}^{2} & -\omega_{1}^{2} \\
-1 & 1
\end{array}\right]\left[\begin{array}{l}
2 \omega_{1} h_{1} \\
2 \omega_{2} h_{2}
\end{array}\right]} \\
\text { 減衰係数 } \quad \boldsymbol{C}=a_{0} \boldsymbol{M}+a_{1} \boldsymbol{K}
\end{gathered}
$$

剛性比例型の減衰係数の推定式

$$
\begin{gathered}
a_{2}=\frac{2 h_{1}}{\omega_{1}} \\
\text { 減衰係数 } \quad \boldsymbol{C}=a_{2} \boldsymbol{K}
\end{gathered}
$$

ここに， $\omega_{1} ， \omega_{2}$ はそれぞれ 1 次，2 次モードの固有円振動数,

$h_{1}, h_{2}$ は 1 次, 2 次モードの減衰定数, $\boldsymbol{M}$ は質量マトリックス, $\boldsymbol{K}$ は剛性係数マトリックスである。

\section{(2) 構造寸法に対する比例減衰式の係数の特性}

建物の高さの変化に対して比例減衰式（式(13）および式(14)） のパラメータ值がどのような変化を示すのか, 本節ではその課題に ついて検討する。文献 11）には，大学・民間会社 40 余りの機関の 協力を得て日本建築学会の委員会で収集・整理された建築物の減衰 の実測データが示されている。それらのうち， R C系建物に関する 関係として, 図 13, 図 14 が示されている。

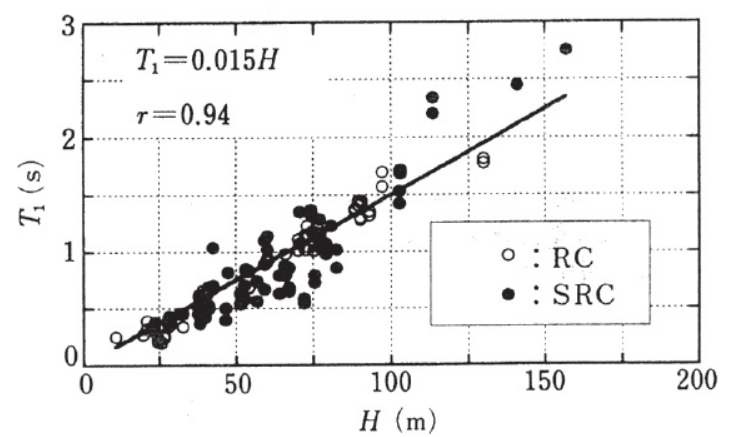

図 13 軒高 $H$ と 1 次固有周期 $T_{1}$ の関係 (文献 11) より引用)

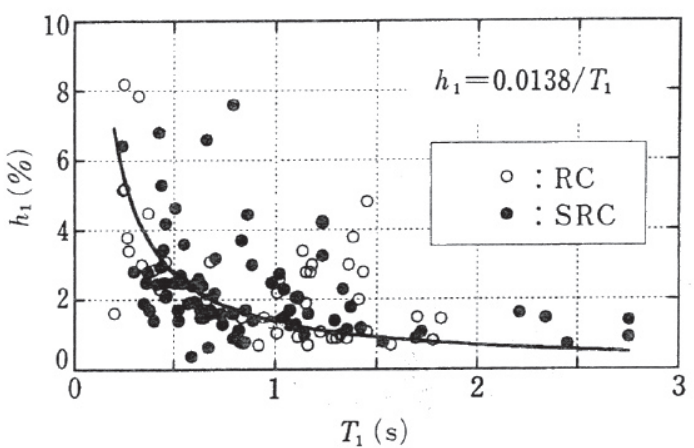

図 141 次固有周期 $T_{1}$ と 1 次減衰定数 $h_{1}$ の関係（文献 $11 ）$ より）

図 13 より軒高 $H(\mathrm{~m})$ と 1 次固有周期 $T_{1}(\mathrm{~s})$ の回帰式として, 次 式が得られている。

$$
T_{1}=0.015 H
$$

また，図 14 については 1 次固有周期 $T_{1}(\mathrm{~s})$ と 1 次減衰定数 $h_{1}$ の 回帰式として次式が得られている。

$$
h_{1}=0.0138 / T_{1}
$$

さらに，R C系建物に関する関係として，次のような実測に基 づく回帰式が示されている。まず, 1 次減衰定数 $h_{1}$ と 2 次減衰 定数 $h_{2}$ の関係として,

$$
h_{2}=1.37 h_{1}
$$

が実測に基づく回帰式として示されている。また，一般的に建物の 2 次固有周期 $T_{2}$ は 1 次固有周期 $T_{1}$ の約 $1 / 3$ とされているのでそれ を採用すれば,

$$
T_{2}=0.333 T_{1}
$$

となる。また，固有円振動数 $\omega_{1}, \omega_{2}$ は次式で求めることができる。

$$
\left[\begin{array}{ll}
\omega_{1} & \omega_{2}
\end{array}\right]=2 \pi\left[1 / T_{1} 1 / T_{2}\right]
$$

そこで, 以上の式(15)〜(19)を式(13), 式(14)に代入することにより, 軒高 $H$ のみを変数に持つレイリー型の係数 $a_{0}, a_{1}$, および岡性比 例型の係数 $a_{2}$ の推定式を得ることができる。図 15 はこのようにし て得られた推定式による建物の軒高 $H$ と係数 $a_{0}, a_{1} ， a_{2}$ の関係を 示している。
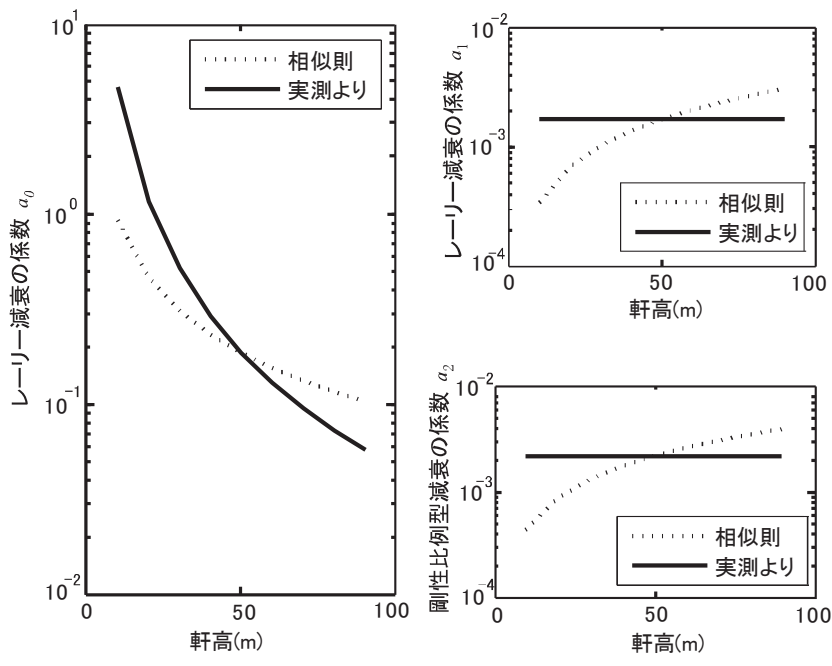

図 15 建物の軒高と減衰に関する係数の関係 
図において実線が以上の関係式による推定值を表している。図に よると実線で示されたレイリー型減衰の係数 $a_{0}$ は軒高 $H$ の変化に 対して大きく変化するが，レイリー型減衰の係数 $a_{1}$ と岡性比例型 減衰の係数 $a_{2}$ は軒高 $H$ の変化に対して変化せず，ほぼ一定值を示 すことがわかる。ここではR C 系建物に限定して結果を示したが, 他の種類の建物構造についても結果はほぼ同じである。

建物を設計する上で, 図 15 のように比例減衰式の係数值が構造寸 法とどのような関係にあり，どのような值を示すのかを明らかにす ることは重要である。さらに, 後節(4)で比例減衰式の倸数 $a_{2}$ と $C_{0}$ の関係について検討し, 図 15 の関係を用いて現実の建物の $\boldsymbol{C}_{0}$ 值を 求める方法を明らかにする。

図 15 には前述した実線以外に点線が表示されているが，これは ある規模の建物や構造物を縮小して実験等を行う場合に相当するも のであり，このような用途に対しても，比例減衰式の係数值が構造 寸法とどのような関係にあり，どのような值を示すのかを明らかに することは同様に重要であるので, 次節(3)で検討する。

図 15 で実線と点線を併記したもう1つの意図は次のとおりであ る。実線と点線は全く相違する条件 (実線は実建物, 点線は減衰又 カニズムの同一性を維持した相似則に従う縮小・拡大)にそれぞれ 対応するものであり, 両者が一致する必要はない。しかし, 両者を 併記してそのずれ（現実の建物特性と点線で示す相似則特性との乘 離)がどうして生じるのかを検討することにより現実の建物でどの ような現象が生じているのかを推測することが可能となるからで ある。

\section{(3) 相似則に基づく比例減衰式の係数の誘導}

図 15 に示寸実線は前述の 3.(2)で文献 11)のデータに基づいて比 例減衰式の倸数を誘導し, 表示されたものである。それに対して, 本節ではそれとは異なる次の条件を満足するように比例減衰式の 係数を誘導し，点線の表示とする。

条件 : 軒高の変化が縮尺率 $(1 / \lambda)$ に比例するとした時, 固有振動 数は相似則 (表 1 )に従って変化する。

ここで，「軒高」を用いるのは，相似則に基づく縮小・拡大を議 論する場合, 構造寸法に関する縮尺比の基準が必ず必要であり, そ れを「軒高」にとっているからである。

しかし，実際の建物における軒高と固有振動数の関係は上述の条 件を満足寸るものではないと考えられる。すなわち，軒高の低い建 物は相対的に横長で, 軒高の高い高層建築は相対的に縦長な形状を していることが多い。つまり形状の相似性は保持されていない。こ れに伴って部材の相似性にも変化が生じていると考えられる。例え ば，軒高が $1 / 5$ であったとしても，床荷重や法の制約から，柱や梁 のサイズが $1 / 5$ になることはない。この場合, 軒高の縮尺率に比し て相対的に大きな部材となり,「見掛けの減衰」などが大きくなる 可能性が考えられる。

確かに, 図 14 とその回帰式である式(16)にはその傾向が見られる。 つまり, 式(16)の左辺の 1 次減衰定数の相似則は「 $1 」$ であるが, 式(16)の右辺(一次固有周期に関する項)の相似則は「入」であり, 左 辺と右辺の相似則に不一致がある。相似則 (表 1 参照)を満足するよ うに式(16)を修正すると次式となる。

$$
h_{1}=0.0138 /\left(\lambda T_{1}\right)
$$

他方，上述の条件があてはまる場合もある。それは現実の建物に 対して減衰メカニズムの同一性を維持した状態 $(\boldsymbol{C}$ 感同一な状態) で, 相似則に従う縮小・拡大構造物が製作される場合である。あるいは, サイズの異なる模型間でこの条件が満足される場合である。このよ うな場合を適用対象と寸る比例減衰の係数式を導く。

前述の 3.(2)では文献 11)のデータに基づく式(15)〜(19)を式(13), 式(14)に代入することにより, 比例減衰の係数 $a_{0}, a_{1}, a_{2}$ の推定式 を得た。その過程において式(16)のかわりに式(20)を用いて同様に比 例減衰の係数 $a_{0}, a_{1}, a_{2}$ の推定式を導いた結果が図 15 の点線である。 図 15 では軒高 $50 \mathrm{~m}$ の場合の $\lambda$ を 1 として, 各軒高に対する $\lambda$ を軒高 $50 \mathrm{~m}$ に基準を置いて求めているため, 軒高 $50 \mathrm{~m}$ の位置で点線と実線 が交わる表示となっている。

点線で示寸比例減衰係数を実際の設計や実験における利用にあて はめて考える。たとえば，減衰メカニズムの同一性を維持した状態 で軒高 $50 \mathrm{~m}$ の建物を相似則に従って縮小した軒高 $10 \mathrm{~m}$ の建物を製作 し, その減衰係数を推定する場合には図 15 の点線を辿り, 軒高 $10 \mathrm{~m}$ の位置の係数 $a_{0}, a_{1} ， a_{2}$ を採用すれば良い。

軒高 50m の建物以外を基準とする場合は次のとおりである。図 15 において実線と点線の関係がいずれの図においても実線は点線の入 倍の関係にあることに着目する。図 15 において実線上の任意の軒高 位置の比例減衰の係数 $a_{0, o}, a_{1, o}, a_{2,0}$ から，それと $1 / \lambda$ 倍の関係にあ る軒高位置の点線に相当寸る係数值 $a_{0, n}, a_{1, n}, a_{2, n}$ を求めるには，ま ず，元の軒高と $1 / \lambda$ 倍の関係にある軒高位置の実線上の係数値 $a_{0, t}, a_{1, t}, a_{2, t}$ を一旦求める。次に, それらの值を $1 / \lambda$ 倍することに よって, 係数值 $a_{0, n}, a_{1, n}, a_{2, n}$ を求めることができる。

建築構造物の解析において, 比例減衰は必ずしも合理的ではない が，利便性において他に勝るので，様々なサイズの構造物の構造設 計に多用されているのが現状である。その際, 以上の解析で明らか となったように, 比例減衰の係数值は寸法効果や減衰メカニズムの 変化の影響を受けるので, サイズの異なる建物間, あるいは構造物 間で使用する係数值を検討する場合には，図 15 に示寸関係を考慮 すべきと考えられる。その場合，一般的な軒高の異なる建物間で係 数值を検討する場合には図 15 の実線の係数值変化を考慮すべきで あり，減衰メカニズムの同一性を維持した状態 $\left(\boldsymbol{C}_{0}\right.$ が同一な状態 $)$ で相似則に従う縮小・拡大を検討する場合には, 図 15 の点線のよ うな係数值の変化を生じると考えられる。

\section{(4) 軒高の変化に対する $C_{0}$ と $a_{2}$ の関係}

次に前述の 2. (1) で誘導した無次元化減衰係数 $\boldsymbol{C}_{\mathrm{o}}$ と剛性比例型減 衰式の係数 $a_{2}$ の関係について検討する。前述の式(4)を再記する。

$$
\boldsymbol{C}_{\mathrm{o}}=\boldsymbol{K}^{-1} \boldsymbol{C}\left(\boldsymbol{K}^{-1} \boldsymbol{M}\right)^{-0.5}
$$

剛性比例型の減衰係数は次式で与えられる(前述の式(14))。

$$
\boldsymbol{C}=a_{2} \boldsymbol{K}
$$

式(22)を式(21)に代入して,

$$
\boldsymbol{C}_{\mathrm{o}}=a_{2}\left(\boldsymbol{K}^{-1} \boldsymbol{M}\right)^{-0.5}
$$

$a_{2}$ が左辺になるよう式(23)を変形すると，次式を得る。

$$
a_{2}=\boldsymbol{C}_{\mathrm{o}}\left(\boldsymbol{K}^{-1} \boldsymbol{M}\right)^{0.5}
$$

式(24)は $\boldsymbol{C}_{0}$ との $a_{2}$ の関係式であるが, 相似則を用いて誘導されたも のではないので，相似則に従う縮小・拡大をする場合に限らず，一 般的な建物の軒高変化にも適用可能な式である。 
どのような軒高を基準にしても良いが，検討上，仮に軒高 $50 \mathrm{~m}$ を 基準に考える。軒高 $50 \mathrm{~m}$ の建物を相似則に従って1/入に縮小寸る場合 を想定する。式(24)に含まれる $\boldsymbol{C}_{\mathrm{o}}$ は減衰メカニズムの同一性を維持 した状態変化に対しては不変である。また, 軒高 $50 \mathrm{~m}$ 建物の剛性係 数が $\boldsymbol{K}_{\boldsymbol{o}}$, 質量が $\boldsymbol{M}_{\boldsymbol{o}}$ の場合, 表 1 に従えば( $\left.1 / \lambda\right)$ の縮小により $\boldsymbol{K}_{\boldsymbol{o}}$ は $\boldsymbol{K}_{\boldsymbol{o}} / \lambda$ に $\boldsymbol{M}_{\boldsymbol{o}}$ は $\boldsymbol{M}_{\boldsymbol{o}} / \lambda^{3}$ となるため相似則に従う縮小建物の $a_{2}$ は次式と なる。

$$
\begin{aligned}
a_{2} & =\boldsymbol{C}_{\mathrm{o}}\left\{\left(\boldsymbol{K}_{\boldsymbol{o}} / \lambda\right)^{-1} \boldsymbol{M}_{\boldsymbol{o}} / \lambda^{3}\right\}^{0.5} \\
& =\boldsymbol{C}_{\mathrm{o}}\left(\boldsymbol{K}_{\boldsymbol{o}}{ }^{-1} \boldsymbol{M}_{\boldsymbol{o}}\right)^{0.5}(1 / \lambda)
\end{aligned}
$$

式(25)の $a_{2}$ は式(24)による $a_{2}$ の $(1 / \lambda)$ 倍となっている。つまり, 縮小建物の $a_{2}$ は縮小前建物の $a_{2}$ の $(1 / \lambda)$ 倍になることを意味してい る。

軒高と剛性比例型減衰式の係数 $a_{2}$ の関係は図 15 で示したが, 図 16 にはそれにさらに○印と×印の記号を加筆したものである。それ らのうち○印は式(25)の関係を表している。図によると○印と実線 は重なっている。

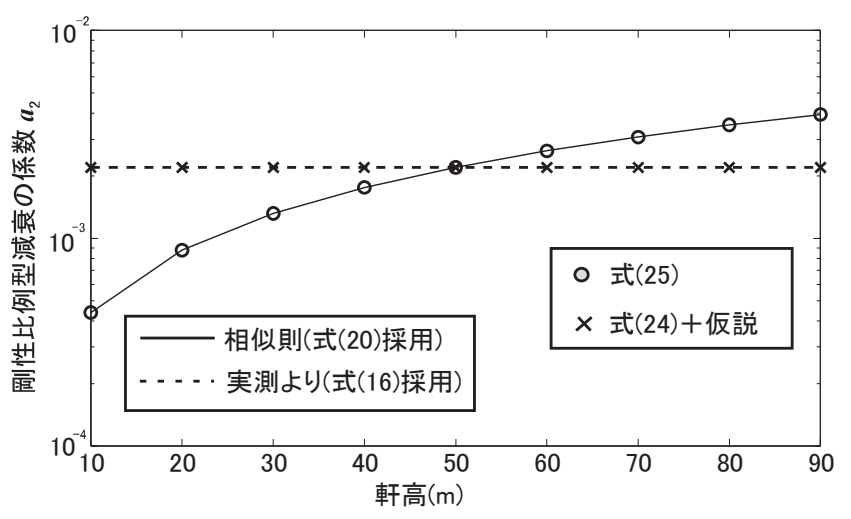

図 16 軒高と剛性比例型減衰式の係数 $\boldsymbol{a}_{2}$ の関係

○印と実線はそれぞれ別の根拠から導かれたものであるが，結果は 同一となるということである。このことから前述の 3. (3)の検討内 容と本節の式 (23) 〜式 (25) の特性は相似則に従う変化に対しては 同一であることがわかる。

実際の建物構造の傾向として, 軒高の低い建物は相対的に横長で, 軒高の高い高層建築は相対的に縦長な形状をしていることが多い。 この場合の軒高の変化に対する剛性係数 $\boldsymbol{K}$ と質量 $\boldsymbol{M}$ の変化につい て次のような仮説を設定し, 以下でその真偽を検証する。

仮説：剛性比例型減衰式が成立する。軒高の変化に対して $\boldsymbol{C}_{\mathrm{o}}$ は不変, $\boldsymbol{K}$ と $\boldsymbol{M}$ は同一の割合で一次比例的に変化する。

「軒高の変化に対して $\boldsymbol{C}_{0}$ が不変」とは, 軒高が変化しても減衰入 カニズムの同一性が維持されることを意味している。次に，「K と $\boldsymbol{M}$ が同一の割合で一次比例的に変化する」とは, 軒高の変化に対し て剛性係数が $\boldsymbol{K}_{\boldsymbol{o}} \rightarrow \mathrm{e} \boldsymbol{K}_{\boldsymbol{o}}$ に, 質量が $\boldsymbol{M}_{\boldsymbol{o}} \rightarrow e \boldsymbol{M}_{\boldsymbol{o}}$ というように変化す ることを意味する。ここに，eは任意の係数である。 式(24)にこれらの関係を代入すると次式を得る。

$$
\begin{aligned}
a_{2} & =\boldsymbol{C}_{\mathrm{o}}\left\{\left(e \boldsymbol{K}_{\boldsymbol{o}}\right)^{-1} e \boldsymbol{M}_{\boldsymbol{o}}\right\}^{0.5} \\
& =\boldsymbol{C}_{\mathrm{o}}\left(\boldsymbol{K}_{\boldsymbol{o}}{ }^{-1} \boldsymbol{M}_{\boldsymbol{o}}\right)^{0.5}
\end{aligned}
$$

式(26)の右辺は式(24)の右辺と式の形は同一である。すなわち,
式(26) は軒高 $50 \mathrm{~m} の a_{2}$ と上記の仮説に従って縮小された建物の $a_{2}$ が 同一であることを意味している。つまり, 軒高の変化に対して $a_{2}$ は 不変ということである。図 16 に示されている×印はこの関係を表し ているが，点線と重なっている。

点線は文献 11)の実測データに基づいており, 他方, ×印は上記仮 説に基づいている。その両者が一致するということは軒高の変化に 対する実際の建物の状態変化が上記仮説で説明できるということで ある。つまり, a) 軒高の変化に対して $\boldsymbol{C}_{\mathrm{o}}$ が不変, b)剛性比例型減衰 式が成立する, という 2 つの仮定が正しければ，軒高の低い建物は 相対的に横長で，軒高の高い高層建築は相対的に縦長な形状をして いるという実際の建物構造に見られる傾向は式(24)において $\boldsymbol{K}$ と $\boldsymbol{M}$ が同一の割合で一次比例的に変化するとして評価できると考えられ る。

また, 実際の建物における無次元化減衰係数 $\boldsymbol{C}_{0}$ の值は式 (23)に実 際の建物の $\boldsymbol{K}$ と $\boldsymbol{M}$, および $a_{2}$ の值を代入することにより推定可能で ある。ここで， $a_{2}$ の值として図 16 の点線の值 $\left(a_{2}=2.2 \times 10^{-3}\right)$ を用 いることができる。それは点線の值が 3. (2) で前述したように文献 11)に示された多くの実際の建物デー夕に基づくものであることに よる。

\section{4. まとめ}

寸法とは無関係に減衰性能を絶対評価できるパラメータ(無次元 化減衰係数)を導き, それを利用したサイズが異なる構造物間におけ る減衰特性の評価法および適用性について検討を行った。その結果, 次のことが明らかとなった。

1) 振動方程式から無次元化減衰係数 $\boldsymbol{C}_{\mathrm{o}}$ を誘導できる。 $\boldsymbol{C}_{\mathrm{o}}$ 值は構造 物の寸法の影響を受けないので, これにより構造物の減衰性能 を絶対評価できる。

2 ) 応答低減比は減衰ゼロの構造に対して, 応答の最大值をどれだ け低減できるかを表す指標であるが，実測データを用いた検討 の結果, 応答低減比と $\boldsymbol{C}_{\mathrm{o}}$ の固有值と間には一定の普遍的な関係 (図 11)の成立することが明らかとなった。この図を利用すれば サイズの異なる任意の構造物の減衰性能のレベルを評価するこ とができると考えられる。

3 ) 実建物の観測データの回帰分析結果に基づいてスケール特性を 考慮した比例減衰式のパラメータ推定式を誘導した(図 15 参 照）。減衰メカニズムの同一性を維持した状態 $\left(\boldsymbol{C}_{\mathrm{o}}\right.$ が同一な状態 $)$ で相似則に従う縮小・拡大を検討する場合の比例減衰式のパラ メータ推定式も併せて誘導し, 同一の図内に示した（図 15 参 照)。

$4 ）$ 剛性比例型減衰式の係数 $a_{2}$ と無次元化減衰係数 $\boldsymbol{C}_{0}$ の関係式を誘 導した。その式を用いた検討の結果、軒高の低い建物は相対的 に横長で，軒高の高い高層建築は相対的に縦長な形状をしてい るという実際の建物構造に見られる傾向は式 (24)において「 $\boldsymbol{K}$ と $\boldsymbol{M}$ が同一の割合で一次比例的に変化する」として評価すると， 実測結果と良く合う。

5 ) 実際の建物における無次元化減衰係数 $\boldsymbol{C}_{0}$ の值は, 実際の建物の $\boldsymbol{K}$ と $\boldsymbol{M}$, および $a_{2}$ の值（図 16 の点線の值 $a_{2}=2.2 \times 10^{-3}$ ）を 式(23)に代入することにより推定可能である。 
参考文献

1) 脇田英治, 田蔵隆, 出羽克之: 新しい高架橋構造の耐震性の検討, 構造工学 論文集, Vol.47A, pp.1213-1220, 2001.3.

2) 風間基樹, 稲富隆昌, 大塚幸治: 遠心力場における振動実験装置の開発,港湾 技研資料, No.607, pp.3-36,1988.3.

3) 吉川正昭，黒岩真彦，山田善一 : 模型地盤を用いた鉄塔一杭基礎一地盤の非 線形連成振動に関寸る実験的研究，土木学会論文集，第 334 号，pp.53-61, 1983.6.

4) 佐野泰之, 成瀬治興, 林健太郎：RC 建築構造物における振動伝搬性状に関 する模型実験,日本建築学会計画系論文集,第 561 号, pp.1-6, 2002.11.

5) 飯場正紀, 田守伸一郎, 北川良和 : 建物一地盤連成系模型の振動台実験によ る杭基礎一の地震作用の基本性状，日本建築学会構造系論文集，第 566 号， pp.29-36, 2003.4.
6) 横川英彰, 中島章香典, 緒方友一, 青戸清剛, 笠松正樹 : 基部からの逸散減 衰の影響を含む高架橋模型の振動実験とその解析，構造工学論文集，Vol. 54A，第 44 号，pp.209-217, 2008.3.

7) 稲井栄一, 藤本利昭, 楊成, 八ツ繁公一 : 粘弾性ダンパー付き鉄骨フレーム の地震応答性状, 鋼構造論文集, 第 11 巻, 第 44 号, pp.63-74, 2004.12.

8) 丸山比佐夫, 片桐純治, 藤井邦雄, 大熊武司 : 高層建築物の弾性模型の開発, 日本風工学会誌，第 11 巻, 第 78 号, pp.45-48, 1999.1 .

9) 多賀直恒, 阿南克俊 : 建物一地盤連成系の地震応答性状に関する研究, 福岡 大学工学集報, 第 78 号, pp.15-22, 2007.3

10)脇田英治 : 初期值設定の影響にロバストな動的パラメータ同定, 構造工学 論文集, Vol.53B, pp.31-38, 2007.3.

11) 日本建築学会 : 建築物の減衰, pp.137-143, 日本建築学会, 2000.

\section{英文要約 (Summary)}

The damping characteristic between different size structures is not fully clarified. Also, the method is not established to convert the damping characteristic between different size structures. The applicability is not enough too. An estimate method that used the parameter $\boldsymbol{C}_{0}$ is proposed in this paper for such problems. The parameter $\boldsymbol{C}_{o}$ is deduced from the vibration equation. Because the parameter $\boldsymbol{C}_{o}$ is dimensionless, the size of the structure is irrelevant to estimate. Therefore, it's possible to estimate the damping performance by using the parameter $\boldsymbol{C}_{o}$ without considering sizing. By utilizing the character of the parameter $\boldsymbol{C}_{o}$, a method is proposed for estimation of the damping characteristics between different size structures. The applicability of the method was proven to be high by using the observed data. In addition, this paper proposes a method to presume the parameter of the proportional damping equation considering the scale effect. The method is deduced based on the results of the regression analysis using the observed data. And, the characteristics of the proposed equation and the relationship with $\boldsymbol{C}_{\mathrm{o}}$ were identified. 